\title{
Diagnostic Performance of Serum $(1,3) \beta-D$ Glucan to Detect Fungal Infection in Acute Leukemia Patients with Chemotherapy
}

\author{
Dian AW ${ }^{1}$, B. Rina A Sidharta ${ }^{1}$, Yuwono Hadi Suparto', Leli Saptawati ${ }^{2}$ \\ ${ }^{1}$ Department of Clinical Pathology, Faculty of Medicine, Sebelas University/Dr. Moewardi Hospital, Surakarta, Indonesia. E-mail: \\ rinaaninda@yahoo.com \\ ${ }^{2}$ Department of Clinical Microbiology, Faculty of Medicine, Sebelas University/Dr. Moewardi Hospital, Surakarta, Indonesia
}

\begin{abstract}
Chemotherapy is a predisposing factor for infection in patients with malignancy, while culture, as the gold standard, limits the diagnosis of fungal infections. (1,3) $\beta$-D glucans, the most abundant polysaccharide component of the fungal wall, are increased in patients with Invasive Fungal Infections (IFI). This research was an analytical observational study with a cross-sectional approach involving 60 acute leukemia patients who received chemotherapy with suspicion of fungal infection at the General Hospital of Dr. Moewardi, Surakarta, from September to October 2019. Fungal blood cultures and serum $(1,3) \beta$-D glucan levels by the enzyme-linked immunoassay method were examined. Diagnostic tests were performed to determine sensitivity, specificity, Positive Predict Value (PPV), Negative Predict Value (NPV), Positive Likehood Ratio (PLR), Negative Likehood Ratio (NLR), and the serum's accuracy value $(1,3) \beta-D$ glucan levels to fungal culture. Most (88.3\%) of patients were diagnosed with Acute Lymphocytic Leukemia (ALL), maintenance chemotherapy phase (51.3\%), risk factors for neutropenia (50\%), and intravenous (IV) line use $(56.7 \%)$. Serum $(1,3) \beta-D$ glucan levels in patients with positive fungal cultures (4) in blood samples had a median of 482.87 (476.13-640.56) pg/mL, while patients with negative fungal cultures (56) had a mean \pm SD $298,68 \pm 114,39 \mathrm{pg} / \mathrm{mL}$. Diagnostic test with a cut-off of $471,717 \mathrm{pg} / \mathrm{mL}$ showed sensitivity of $100.0 \%$, specificity of $96.4 \%$, NPV of $100 \%$, PLR of 28.00 , and NLR of 0.00 with an Area Under Curve (AUC) value of 0.982 and Coefficient Interval (CI) 95\% (0.950-1.014). The measurement of serum $(1,3) \beta-D$ glucan at a cut-off value of $471,717 \mathrm{pg} / \mathrm{mL}$ showed good performance as a biomarker for diagnosing and screening IFIs.
\end{abstract}

Keyword: (1,3) $\beta$-D-glucan, invasive fungal infection, acute leukemia, chemotherapy

\section{INTRODUCTION}

Invasive Fungal Infections (IFIs) are life-threatening complications in leukemic patients with neutropenia. The prevalence of IFI in acute leukemia cases is $38.8 \%{ }^{1}$ Research by Patricia showed that the prevalence of IFI in malignancy cases at the Dr. Moewardi Hospital, Surakarta was $38.2 \%{ }^{2}$ Chemotherapy is a predisposing factor for infection in malignant patients. ${ }^{3}$

A fungal culture is a gold standard in the diagnosis of IFI. The diagnosis of IFI is frequently delayed because it is often difficult to get positive culture results from blood or tissue in a critical patient, and it takes a long time.

Glucan is the central, most influential, and abundant component of the fungal polysaccharide. ${ }^{4,5}$ (1-3)- $\beta$-D-glucans test in high-risk patients has become a crucial non-cultural method for diagnosis of IFI. Serum (1-3)- $\beta$-D-glucans levels can be measured by a kinetic method based on the Limulus Amebocyte Lysate (LAL) pathway. This method has been widely used in research despite its complicated process and limited availability. ${ }^{6,7}$ Another way is Enzyme-Linked Immunosorbent Assay (ELISA), which needs further development and research. ${ }^{6}$ This research aimed to determine the diagnostic performance of serum (1-3) $\beta$-D-glucans using the ELISA method to detect fungal infections in patients with acute leukemia on chemotherapy as a predisposing factor to help clinicians establish early and accurate diagnosis and management of patients.

\section{METHODS}

This research was an analytical observational study with a cross-sectional approach, which involved 60 patients with acute leukemia on chemotherapy with IFI suspicion between September-October 2019 at Dr. Moewardi Hospital, Surakarta. Inclusion criteria included all patients with acute leukemia who had been diagnosed based on the results of routine blood tests, peripheral blood smear, bone marrow smear, had received chemotherapy, and patients who had one or more 
risk factors for fungal infections (fever $>$ three days, neutropenia (neutrophils $<500$ cells $/ \mu \mathrm{L}$ ), lymphopenia (lymphocytes $<500$ cells $/ \mu \mathrm{L}$ ), patients with urinary catheters, patients with intravenous lines, corticosteroid therapy $>1$ week, antibiotic therapy > 1 week); and patients who approved and signed informed consent. Exclusion criteria were patients who had received antifungal therapy based on anamnesis and medical records.

Subject's data that met the inclusion criteria during the specified time period were then collected through medical records, anamnesis, and physical examination to complete the patient characteristic data until the number of samples was fulfilled (consecutive random sampling). Blood samples were withdrawn from 3-5 $\mathrm{mL}$ to be examined by Matrix-Assisted Laser Desorption Ionization-Mass Spectrometry (MALDI-TOF-MS) followed by fungal culture and measurement of serum $(1,3) \beta$-D-glucan levels (BDG ELISA kit, MyBioSource). This research has been approved by the Dr. Moewardi Hospital Ethics

\section{RESULTS AND DISCUSSIONS}

Table 1. Basic characteristics of research subjects

\begin{tabular}{|c|c|c|c|}
\hline Characteristic & F (\%) & Mean \pm SD & Median (percentile 25-75) \\
\hline Age & & & $9.50(6.25-14.75)$ \\
\hline \multicolumn{4}{|l|}{ Gender } \\
\hline Male & 28 (46.7\%) & & \\
\hline Female & 32 (53.3\%) & & \\
\hline \multicolumn{4}{|l|}{ Diagnosis } \\
\hline ALL & 53 (88.3\%) & & \\
\hline AML & 7 (11.7\%) & & \\
\hline \multicolumn{4}{|l|}{ Phase of chemotherapy } \\
\hline Induction phase & $16(26.7 \%)$ & & \\
\hline Consolidation phase & $4(6.7 \%)$ & & \\
\hline Maintenance phase & 31 (51.7\%) & & \\
\hline Reinduction phase & $2(3.3 \%)$ & & \\
\hline AML regiment & 7 (11.7\%) & & \\
\hline \multicolumn{4}{|l|}{ Risk factor } \\
\hline Fever $>3$ days & $12(2.0 \%)$ & & \\
\hline Neutropenia & 30 (50.0\%) & & \\
\hline Use of urine catheter & $0(0.0 \%)$ & & \\
\hline Use of IV line & 34 (56.7\%) & & \\
\hline Antibiotic therapy $>1$ week & $17(28.3 \%)$ & & \\
\hline Corticosteroid therapy $>1$ week & $18(30.0 \%)$ & & \\
\hline Hemoglobin $^{a}(g / d L)$ & & $10.83 \pm 1.85$ & \\
\hline Leukocytes (cells/ $\mu \mathrm{L}$ ) & & $3906,67 \pm 1645,11$ & \\
\hline Platelets $\left(\mathrm{X} 10^{3} / \mu \mathrm{L}\right)$ & & & $215,00(78.25-296,00)$ \\
\hline Absolute neutrophils (cells/ $\mu \mathrm{L}$ ) & & $1439,70 \pm 809,18$ & \\
\hline Absolute lymphocytes (cells/ $\mu \mathrm{L}$ ) & & $1890,52 \pm 1143,87$ & \\
\hline
\end{tabular}

Note: a. Data distribution was normal (meana \pm SD); b. Data distribution was abnormal (median $\left(25^{\text {th }}-75^{\text {th }}\right.$ percentile); $S D=S t a n d a r d$ Deviation, ALL= Acute Lymphoblastic Leukemia, AML= Acute Myeloblastic Leukemia, F=frequency, $\mathrm{IV}=$ intravenous, $\mathrm{g} / \mathrm{dL}=\mathrm{gram} / \mathrm{desilitre}$, $\mu \mathrm{L}=$ microlitre, $\%=$ percent 
Table 2. Characteristics of research variable: $(1,3) \beta-D$ glucan and fungal culture

\begin{tabular}{lccc}
\hline \multirow{2}{*}{ Research Variable } & \multicolumn{2}{c}{ Blood Culture } & \multirow{2}{*}{ P } \\
\cline { 2 - 3 } & Positive $(\mathrm{n}=4)$ & Negative $(\mathrm{n}=56)$ & \\
\hline$(1,3) \beta$-D-glucan $(\mathrm{pg} / \mathrm{mL})$ & $482,87(476,13-640,56)$ & $298,68 \pm 114,39$ & 0.0001 \\
\hline
\end{tabular}

Note: data were presented as median $\left(25^{\text {th }}-75^{\text {th }}\right.$ percentile) due to abnormal distribution; the difference was determined using Mann-Whitney test. Significant if $p<0.05 ; \mathrm{pg} / \mathrm{mL}=$ picogram $/$ mililitre, $n=$ number of samples, $p=$ significance value

Based on the inclusion and exclusion criteria, a total of 60 subjects was involved, consisting of $88.3 \%$ patients with a clinical diagnosis of ALL and $51.7 \%$ patients with the maintenance phase of chemotherapy. Complete data of the basic characteristics of subjects can be seen in Table 1.

Based on Table 2, the median of serum $(1,3) \beta$-D-glucan levels in patients with positive fungal blood cultures was 482,87 (476,13-640,56) $\mathrm{pg} / \mathrm{mL}$, while the mean $\pm \mathrm{SD}$ of serum $(1,3) \beta$-D-glucan levels in patients with negative fungal blood cultures was $298,68 \pm 114,39 \mathrm{pg} / \mathrm{mL}$. Mann-Whitney test results showed a significantly different result of serum (1-3) $\beta$-D-glucan levels between patients with positive and negative fungal blood cultures in this study with $p$-values $<0.05$.

The cut-off value was determined using the ROC curve (Figure 1). The cut-off value of serum $(1,3) \beta$-D glucan level obtained from the ROC curve was $471.72 \mathrm{pg} / \mathrm{mL}$ with an AUC value of 0.982 and Confident Interval (CI) of 95\% (0.950-1.014). The diagnostic performance of $(1,3) \beta-D$ serum glucan levels was compared to the gold standard method of fungal culture.

Based on the $2 \times 2$ table (Table 3 ), it was found that four patients with positive fungal blood cultures had serum (1-3) - $\beta$-D-glucan levels > 471,72 pg/mL, while most (54) of 56 patients with negative fungal blood cultures had serum (1-3) - $\beta$-D-glucan levels < $471.72 \mathrm{pg} / \mathrm{mL}$. Besides, compared to fungal blood culture as a gold standard, serum (1-3) - $\beta$-D-glucan levels had sensitivity, specificity, NDN, PLR, and NLR of $100.0 \%, 96.4 \%, 100 \%, 28.00,0.00$ with an AUC value of $0.982 \mathrm{CI} 95 \%(0.950-1.014)$, respectively in detecting fungal infections in patients with acute leukemia on chemotherapy.

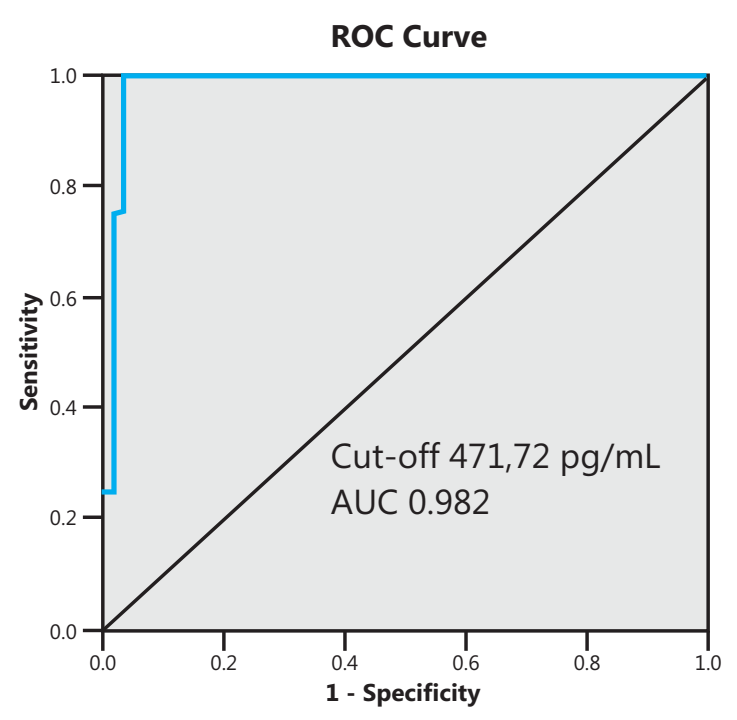

Figure 1. ROC curve

The most commonly found diagnosis of this study was ALL (88.3\%). This result was different from the study by Bartlet et al., which found that the prevalence of IFI in AML malignancies was greater (28.2\%) compared to ALL (10\%) among all malignancies. ${ }^{1}$ Acute leukemia is the most common malignancy in children. Based on data from acute leukemia visits in the Dr. Moewardi Hospital in 2018, it was found that the percentage of ALL patient visits was greater (73\%) compared to AML (27\%).

The maintenance phase of chemotherapy was most commonly found in this study (51.7\%), followed by the induction phase (26.7\%). This result was different from the study by Pagano et al., which stated that the highest risk of IFI in leukemia was in the induction phase of chemotherapy. ${ }^{8}$ Based on Cancer Research 2018, the consolidation phase of chemotherapy in ALL is performed in the long term

Table 3. $2 \times 2$ table of the diagnostic test of serum $(1,3) \beta$-D glucan compared to fungal culture as a gold standard

\begin{tabular}{|c|c|c|c|}
\hline \multirow{2}{*}{ Serum $(1,3) \quad \beta$-D-Glucan Levels $(\mathrm{pg} / \mathrm{mL})$} & \multicolumn{2}{|c|}{ Fungal Blood Culture } & \multirow{2}{*}{ Tota } \\
\hline & Positive & Negative & \\
\hline$\geq 471,72$ (positive) & 4 & 2 & 6 \\
\hline$<471,72$ (negative) & 0 & 54 & 54 \\
\hline Total & 4 & 56 & 60 \\
\hline
\end{tabular}

Note $\mathrm{pg} / \mathrm{mL}=$ picogram/milliliter 
with small doses, accompanied by steroid administration for approximately two years and sometimes in conjunction with antibiotics. ${ }^{9}$

The highest risk factor for IFI in the patients in this study was the use of IV lines (50.7\%) and neutropenia (50\%). This data was following research by Lien et al., which showed that the condition of neutropenia in malignant patients with chemotherapy was twice more likely to suffer from IFI. ${ }^{10}$

The number of patients with negative fungal cultures was greater than the patients with negative fungal cultures. Clinical manifestations of IFI are difficult to prove with blood culture. Sampling for blood culture in this study was merely performed once. A one-time sampling strategy can produce many positive culture results, but taking more than one blood sample is sometimes also necessary. ${ }^{11}$ Serum $(1,3) \beta$-D-glucan levels in this study ranged from 206,92-640,56 $\mathrm{pg} / \mathrm{mL}$. Median of serum $(1,3) \quad \beta$-D-glucan levels in patients with positive fungal cultures was $482.87(476,13-640,56) \mathrm{pg} / \mathrm{mL}$, whereas patients with negative fungal cultures had mean \pm SD $298,68 \pm 114,39 \mathrm{pg} / \mathrm{mL}$. Research by Azoulay et al. obtained serum (1-3) $\beta$-D-glucan levels of 144 (77-510) and 50 (30-125) pg/mL in a group of hematologic malignancy with IFI and the group without IFI. ${ }^{12}$

Serum levels (1-3) $\beta$-D-glucan had an excellent performance as a diagnostic biomarker of fungal infections in patients with acute leukemia on chemotherapy with excellent AUC values (> 0.9-1). Sensitivity and specificity of serum (1-3) $\beta$-D-glucan levels $>90 \%$ indicated that biomarkers could not merely be used as a diagnostic instrument but could also be used as screening instruments. Good diagnostic value was indicated by PLR $>10$ and NLR close to 0 .

\section{CONCLUSIONS AND SUGGESTIONS}

Based on the research involving 60 samples of acute leukemia patients on chemotherapy with suspicion of IFI, it could be concluded that the serum $(1,3) \beta-D$ glucan has an excellent performance to diagnose fungal infections in acute leukemia patients on chemotherapy with comparison to fungal culture as a gold standard. Further research involving acute leukemia patients with suspicion of IFI, healthy control, and the use of other body fluid than serum was needed.

\section{REFERENCES}

1. Bartlett AW, Cann MP, Yeoh DK, Bernard A, Ryan AL, et al. Epidemiology of invasive fungal infections in immunocompromised children; An Australian national 10-year review. Pediatric Blood \& Cancer, 2018; 66(4): e27564.

2. Patricia T. Pola jamur dan resistensi antijamur pada pasien dengan penyakit keganasan di RSUD Dr. Moewardi Surakarta periode Januari-Desember 2019. Karya stase Mikrobiologi. Program Pendidikan Spesialis Patologi Klinik, Fakultas Kedokteran Universitas Sebelas Maret Surakarta. 2019.

3. Crawford J, Dale DC, Lyman GH. Chemotherapy-induced neutropenia: Risks, consequences, and new directions for its management. Cancer, 2004; 100(2): 228-237.

4. Latgé JP. The cell wall: A carbohydrate armor for the fungal cell. Mol Microbiol, 2007; 66(2): 279-290.

5. Wright WF, Overman SB, Ribes JA. (1-3) $\beta$-D-glucan assay: A review of its laboratory and clinical application. Laboratory Medicine, 2011; 42(11): 679-85.

6. Iossifova Y, Reponen T, Daines M, Levin L, Hershey GKK. Comparison of two analytical methods for detecting $(1,3) \beta-D$ glucan in pure fungal cultures and in-home dust sample. The Open Allergy Journal, 2018; 1:26-34.

7. Anonim. Lipopolysaccharides (LPS) ELISA kit may substitute for Limulus Amebocyte Lysate (LAL) test reagen. Cloud-clone corp; Http www-cloud clone.com/topic/201305071641290001.html. 2013. (accessed 14 October, 2019).

8. Pagano L, Mayor S. Invasive fungal infections in high-risk patients: Report from TIMM-8 2017. Future Science OA, 2018; 4(6): 1-10.

9. Cancer Research UK. Acute lymphoblastic leukemia phase treatment, diunduh dari https://www. cancerresearchuk.org/about-cancer/ acute-Iymphoblastic-Ieukaemia-all/ treatment/phases. 2018. (accessed 14 October, 2019).

10. Lien MY, Chou CH, Lin CC, Bai LY, Chiu CF, et al. Epidemiology and risk factors for invasive fungal infections during induction chemotherapy for newly diagnosed acute myeloid leukemia: A retrospective cohort study. PLos One, 2018; 13(6): e0197851.

11. Brigitte $L$, Pascal R, Gérard $C$, Jean-Pierre F, Marie $L$. What is the relevance of obtaining multiple blood samples for culture? A comprehensive model to optimize the strategy for diagnosing bacteremia. Clinical Infectious Diseases, 2002; 35(7): 842-850.

12. Azoulay $E$, Guigue $N$, Darmon $M$, Mokart $D$, Lemiale $V$, et al. $(1,3)-\beta$-D-glucan assay for diagnosing invasive fungal infections in critically ill patients with hematological malignancies. Oncotarget, 2016; 7(16): 21484-21495. 